\title{
PERANCANGAN AUTOMATIC VOLTAGE REGULATOR (AVR) BERBASIS PENGATURAN TEGANGAN CATU DAYA ARUS SEARAH INVERTER 1 FASE SINUSOIDAL PULSE WIDTH MODULATION (SPWM) SINEWAVE
}

\author{
Yoshua Habibnur ${ }^{*}$, Agung Warsito dan Iwan Setiawan \\ Departemen Teknik Elektro, Universitas Diponegoro \\ Jl. Prof. Sudharto, SH, Kampus UNDIP Tembalang, Semarang 50275, Indonesia \\ ${ }^{*}$ E-mail: yhabibnur@gmail.com
}

\begin{abstract}
Abstrak
Indonesia ternyata tidak sepadan dengan kualitas listrik yang diberikan oleh PT. PLN. Tegangan PLN paling rendah yaitu $170 \mathrm{~V}$ yang terdapat di beberapa kota. Tidak tercapainya rating tegangan dapat menyebabkan peralatan elektronik tidak bekerja secara maksimal dan berpotensi mengalami kerusakan. Salah satu tujuan penelitian ini yaitu merancang sebuah konverter sebagai solusi dari permasalahan jatuh tegangan dan kestabilan tegangan, yaitu automatic voltage regulator (AVR) menggunakan inverter 1 fase teknik pemicuan sinusoidal pulse width modulation (SPWM) dengan pengaturan tegangan DC. Topologi pengatur tegangan DC yang digunakan adalah DC chopper buck-boost teknik pemicuan pulse width modulation (PWM) dengan umpan balik di sisi keluarannya. Perancangan dilakukan berdasarkan ketentuan literatur terkait, simulasi PSIM 9.0 dan MATLAB 2014a. Konverter dengan sistem AVR diharapkan dapat mencapai tegangan rating dan stabil pada level $207-241 \mathrm{~V}$ sesuai standar SPLN 1:1995. Berdasarkan hasil pengujian variasi tegangan sumber dari 170 - $200 \mathrm{~V}$ dengan sistem AVR, konverter dapat mencapai tegangan rata - rata pada sisi DC dan AC berturut - turut sebesar $229,5 \mathrm{~V}$ dan $228,56 \mathrm{~V}$ dengan frekuensi rata - rata 50,25 Hz. Efisiensi rata -rata yang dapat dicapai oleh konverter sebesar 72,02\% pada kondisi sistem AVR bekerja.
\end{abstract}

Kata Kunci: Automatic Voltage Regulator (AVR), DC Chopper Buck-boost, Kestabilan Tegangan, Inverter, SPWM

\begin{abstract}
Indonesia is a vast archipelago country with electrification ratio of $88.30 \%$. Electrical equity in Indonesia was not commensurate with the quality of electricity provided by PT. PLN. The lowest grid voltage is $170 \mathrm{~V}$ located in several cities. Unachieved voltage to its rating can cause electronic equipments do not work well and potentially damaged. One of the objectives of this research is to design a converter as a solution for voltage drop and voltage stability problems, and it is automatic voltage regulator (AVR) using inverter 1 phase sinusoidal pulse width modulation (SPWM) triggering technique with DC voltage setting. The used DC voltage control topology is DC chopper buck-boost pulse width modulation (PWM) pulse technique with feedback on the output side. The design is done based on the related literature review, PSIM 9.0 and MATLAB 2014a simulations. Converter with AVR system is expected to achieved its voltage rating and stable at level $207-241 \mathrm{~V}$ according to SPLN 1: 1995 standard. Based on testing result of source voltage variation from 170 - $200 \mathrm{~V}$ with AVR system, converter can reach the average voltage on DC and AC side respectively $229,5 \mathrm{~V}$ and $228,56 \mathrm{~V}$ with average frequency $50,25 \mathrm{~Hz}$. The average efficiency that can be achieved by the converter is $72.02 \%$ under conditions of the AVR system working.
\end{abstract}

Keywords: Automatic Voltage Regulator (AVR), DC Chopper Buck-boost, Voltage stability, Inverter, SPWM

\section{Pendahuluan}

Indonesia merupakan negara kepulauan yang terdiri dari 17.503 pulau yang tersebar dari Sabang hingga Merauke. Salah satu tolak ukur kemakmuran warga negaranya adalah kebutuhan akan pasokan listrik. Rasio elektrifikasi Indonesia telah mencapai $88,30 \%$ pada akhir tahun 2015 [1]. Nilai ini dinilai baik untuk negara yang sangat luas. Seiring dengan pemerataan listrik di Indonesia, ternyata tidak selaras dengan kualitas listrik yang diberikan oleh PLN (Perusahaan Listrik Negara) sebagai pengelola tunggal kelistrikan Indonesia. Terdapat di kota Jakarta, Balikpapan, dan Maros dilaporkan bahwa tegangan PLN tidak stabil dan dapat mencapai tegangan paling rendah $170 \mathrm{~V}$ dengan nilai tegangan normal $220 \mathrm{~V}$ [2], [3], [4]. Tegangan yang tidak stabil dan tidak mencapai rating tegangan dapat menyebabkan peralatan elektronik seperti lampu, pendingin ruangan, komputer, dan motor proses 
industri tidak bekerja secara maksimal dan berpotensi mengalami kerusakan. Kestabilan tegangan peralatan dapat dijaga stabil dengan menggunakan sebuah pengatur tegangan automatis yang dapat mempertahankan tegangan kerja peralatan. Skema kerja tersebut salah satunya dapat direalisasikan dengan menggunakan inverter 1 fase dengan pengaturan tegangan DC.

Penelitian ini akan dirancang sebuah modul perangkat keras inverter 1 fase dengan pengaturan tegangan DC oleh DC chopper buck-boost. Teknik pemicuan yang digunakan untuk inverter 1 fase adalah sinusoidal pulse-width modulation (SPWM) serta implementasi pengatur tegangan automatis/automatic voltage regulator (AVR) pada DC chopper buck-boost.

\section{Metode}

Perancangan alat pada penelitian ini terdiri 2 bagian yaitu rangkaian daya dan rangkaian kontrol. Rangkaian daya terdiri dari sumber AC 1 fase, full-bridge rectifier, DC chopper buck-boost, inverter 1 fase, dan filter $L-C$. Rangkaian kontrol terdiri dari mikrokontroler pembangkit PWM, SPWM generator.

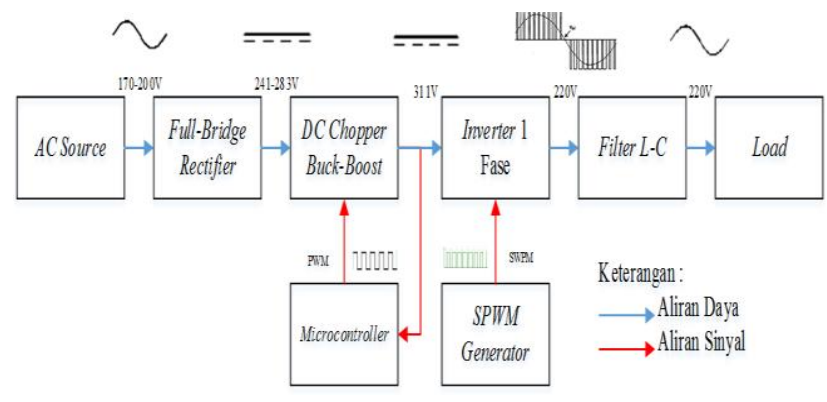

Gambar 1. Diagram blok perancangan perangkat keras

Spesifikasi automatic voltage regulator berdasarkan Gambar 1 yang dirancang pada Penelitian ini dijelaskan sebagai berikut:

1. Sumber tegangan AC 1 fase digunakan untuk mensuplai rangkaian daya dengan kasus tegangan tidak stabil (170-200V) dan rangkaian kontrol.

2. Mikrokontroler berupa Arduino UNO R3 digunakan untuk menghasilkan sinyal kontrol pemicuan pulsewidth modulation (PWM) untuk DC chopper buckboost serta umpan balik tegangan DC chopper buckboost untuk menjaga tegangan stabil dilevel tegangan $311 \mathrm{~V}$.

3. Jenis DC chopper yang digunakan adalah DC chopper buck-boost yang merupakan penaik dan penurun tegangan suplai DC untuk inverter. DC chopper ini terdiri dari 1 buah MOSFET FMH23N50E, dioda MUR1560, kapasitor dan induktor.

4. Jenis inverter yang dirancang adalah voltage-source inveter (VSI) satu fase, yang terdiri dari 4 buah IGBT tipe G40N120.

\subsection{Perancangan Full-bridge Rectifier}

Penyearah rangkaian daya DC chopper yang digunakan adalah jenis penyarah gelombang penuh jembatan. Penyearah ini menggunakan dioda bridge yang terdiri dari 4 dioda didalamnya yang tersusun seperti jembatan berfungsi menyearahkan suplai AC 1 fase [5]. Dioda bridge yang digunakan adalah KBPC3510 dengan spesifikasi arus $35 \mathrm{~A}$ dan tegangan puncak $1000 \mathrm{~V}$ [6] .

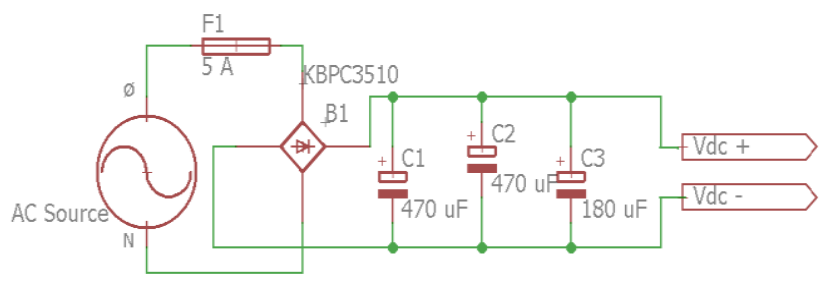

Gambar 2. Rangkaian full-bridge Rectifier

\subsection{Perancangan DC Chopper Buck-boost}

Pemilihan DC chopper buck-boost didasari oleh penggunaan aplikasi AVR yang membutuhkan karakteristik penaik dan penurun tegangan. Keuntungan lain dari jenis konverter ini adalah kebutuhan komponen yang lebih sedikit dibandingkan konverter DC-DC lain penaik-penurun tegangan lainnya. DC chopper cúk dan SEPIC membutuhkan 2 buah komponen induktor dan kapasitor sedangkan DC chopper buck-boost hanya membutuhkan 1 buah komponen induktor dan kapasitor. DC chopper buck-boost memiliki keluaran tegangan DC negatif sehingga untuk aplikasi tegangan positif, terminal keluaran harus dibalik. Keluaran DC chopper buck-boost ini digunakan sebagai masukan inverter 1 fase. Spesifikasi komponen penyusun DC chopper buck-boost ditentukan berdasarkan tegangan ranah kerja sesuai Gambar 1 serta perhitungan komponen inductor dan kapasitor berdasarkan kinerja konverter dalam keadaan continuous current mode (CCM) [7]

Tabel 1. Komponen rangkaian DC chopper buck-boost

\begin{tabular}{cc}
\hline Komponen & Tipe/Nilai \\
\hline MOSFET & FMH23N50E \\
Dioda & MUR1560 \\
Induktor & $5 \mathrm{mH}$ \\
Kapasitor & 2 buah $470 \mu \mathrm{F} / 470 \mathrm{~V}$ \\
& 1 buah $330 \mu \mathrm{F} / 430 \mathrm{~V}$ \\
\hline
\end{tabular}

Tegangan keluaran DC chopper buck-boost memiliki karakteristik seperti pada Persamaan 1 berikut ini [8].

$V_{o}=\frac{V_{S} \cdot D}{(1-D)}$

dimana

$$
\begin{array}{ll}
\mathrm{V}_{\mathrm{o}} & =\text { Tegangan keluaran DC }(\mathrm{V}) \\
\mathrm{Vs} & =\text { Tegangan sumber DC }(\mathrm{V}) \\
\mathrm{D} & =\text { Duty cycle }(0 \ldots 1)
\end{array}
$$




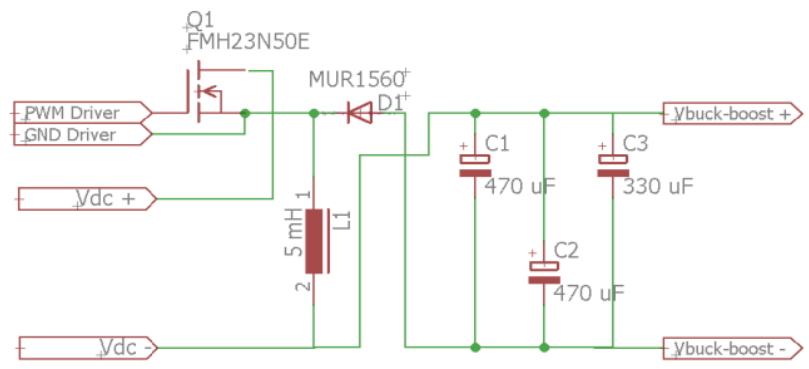

Gambar 3. Rangkaian DC chopper buck-boost

\subsection{Perancangan Inverter 1 Fase}

Rangkaian inverter pada Penelitian ini berfungsi agar tegangan yang telah distabilkan oleh DC chopper buckboost dapat digunakan untuk aplikasi AC. Teknik pemicuan yang dipilih adalah modified unipolar SPWM karena memiliki efisiensi yang paling baik dibandingkan tipe pemicuan SPWM lainnya [9], [10] selain itu memiliki harmonisa yang sama dengan unipolar SPWM. Harmonisa dapat diredam dengan implementasi filter $L-C$.

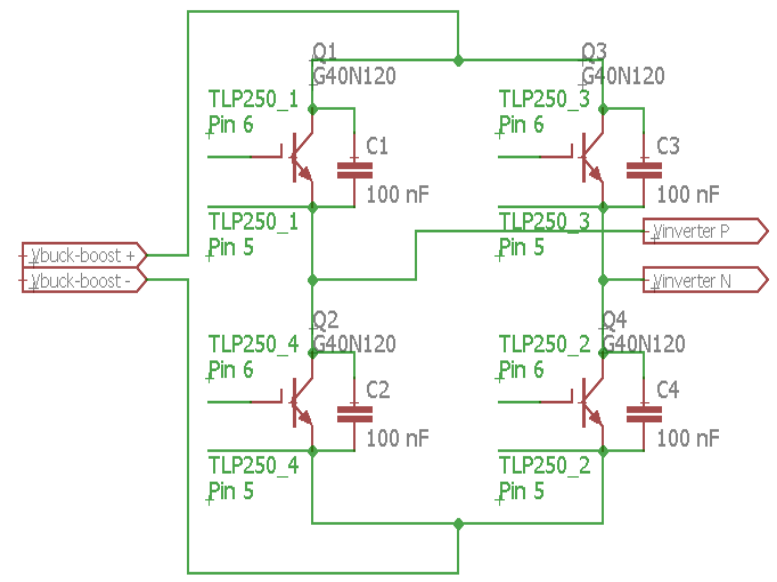

Gambar 4. Rangkaian inverter 1 fase

Rangkaian daya inverter 1 fase full-bridge terdiri dari 4 IGBT yang disusun menyerupai huruf H. Gate-emitter masing-masing IGBT diberi pemicuan SPWM sesuai dengan runtut kerja inverter. IGBT yang digunakan G40N120 yang mempunyai Breakdown Drain-Source $V_{(B R) D S}$ sebesar $1200 \mathrm{~V}$ dan memiliki kemampuan arus continuous drain maksimal 25 A pada suhu $100^{\circ}$ celsius [11].

Tegangan keluaran inverter 1 fase memiliki karakteristik seperti pada Persamaan 2 berikut ini [5].

$V_{A C} r m s=\frac{M_{a} \cdot V_{d c}}{\sqrt{2}}$

dimana

$\mathrm{V}_{\mathrm{AC}}$ rms = Tegangan keluaran Inverter $(\mathrm{V})$

$M_{a} \quad=$ Indeks Modulasi $(0 \ldots . .1)$

$\mathrm{V}_{\mathrm{dc}} \quad=$ Tegangan masukan inverter $(\mathrm{V})$

\subsection{Perancangan Filter $L-C$}

Untuk mendapatkan tegangan keluaran inverter dengan total harmonic distorsion (THD) yang relatif kecil dibutuhkan low-pass filter (LPF). LPF bekerja dengan melewatkan frekuensi yang lebih rendah dari frekuensi cutout, sehingga harmonisa frekuensi tinggi dapat dihilangkan. Frekuensi cut-out ditentukan dengan cara melakukan analisis fast fourier transform (FFT) keluaran tegangan inverter 1 fasa. THD rendah dapat dicapai jika nilai damping ratio respon frekuensi mencapai nilai 0.707 [12]. Frekuensi cut-out yang dipilih adalah $150 \mathrm{~Hz}$ karena frekuensi setelahnya memiliki tegangan harmonik yang lebih besar berdasarkan simulasi MATLAB 2014a. Komponen L dan C didapatkan dengan Persamaan 3 dan 4 berikut ini.

$$
\begin{aligned}
& C=\frac{1}{2 \pi f_{c} R_{L} \sqrt{2}} \\
& L=\frac{R_{L} \sqrt{2}}{2 \pi f_{c}}
\end{aligned}
$$

dimana

$$
\begin{aligned}
\mathrm{C} & =\text { Kapasitansi kapasitor }(\mathrm{H}) \\
\mathrm{L} & =\text { Induktansi induktor }(\mathrm{L}) \\
\mathrm{R}_{\mathrm{L}} & =\text { Resistansi beban }(\Omega) \\
f_{c} & =\text { Frekuensi cut-out }(\mathrm{Hz})
\end{aligned}
$$

Berdasarkan persamaan 3 dan 5, didapat nilai Kapasitor dan induktor hasil perhitungan sebesar 7,5 $\mu \mathrm{F}$ dan $150 \mathrm{mH}$. Untuk mempermudah implementasi rangkaian dan mendapatkan filter yang lebih baik, maka dipilih komponen kapasitor dan induktor sebesar 9,4 $\mu \mathrm{F}$ dan 160 $\mathrm{mH}$.

\subsection{Perancangan Mikrokontroler pembangkit PWM}

PWM sebagai pemicuan DC chopper buck-boost, dihasilkan dengan menggunakan Arduino UNO R3. Pembangkitan PWM dapat dipermudah dengan menggunakan library timerone.h. Nilai duty cycle PWM dapat diubah dengan menggunakan 2 cara, yaitu open-loop dan close-loop. Mode open-loop digunakan dengan cara memindahkan tuas ke mode open-loop dan memutar potensiometer., sedangkan mode close-loop digunakan dengan cara memindahkan tuas ke mode close-loop seketika duty cycle akan berubah menyesuaikan tegangan yang diinginkan. Mode close-loop ini-lah yang digunakan sebagai sistem utama AVR. Setpoint yang ditentukan senilai $311 \mathrm{~V}$, sehingga inverter 1 fase dapat mencapai tegangan $220 \mathrm{~V}$. 


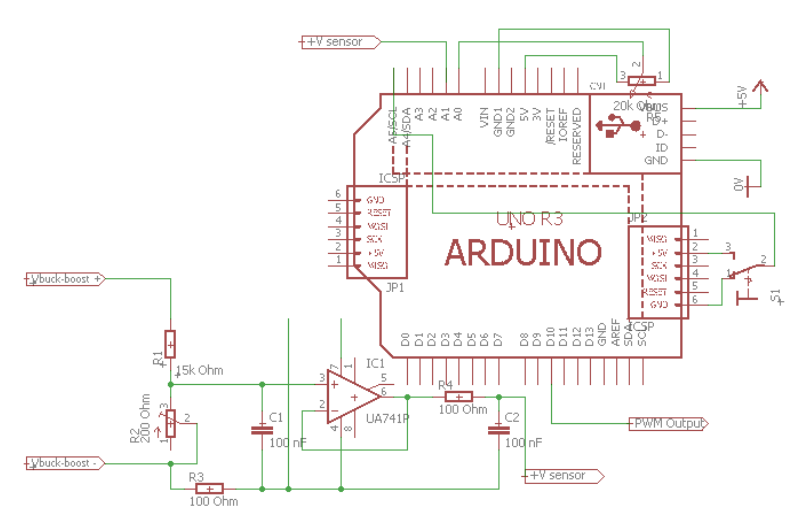

Gambar 5. Rangkaian mikrokontroler pembangkit PWM

\subsection{Perancangan Rangkaian SPWM Generator}

Gelombang SPWM merupakan komparasi antara gelombang segitiga dan sinus, jika nilai tinggi gelombang sinus lebih kecil dari gelombang segitiga maka logika keluaran bernilai HIGH dan jika sebaliknya bernilai LOW. Metode yang digunakan adalah modified unipolar SPWM [13].
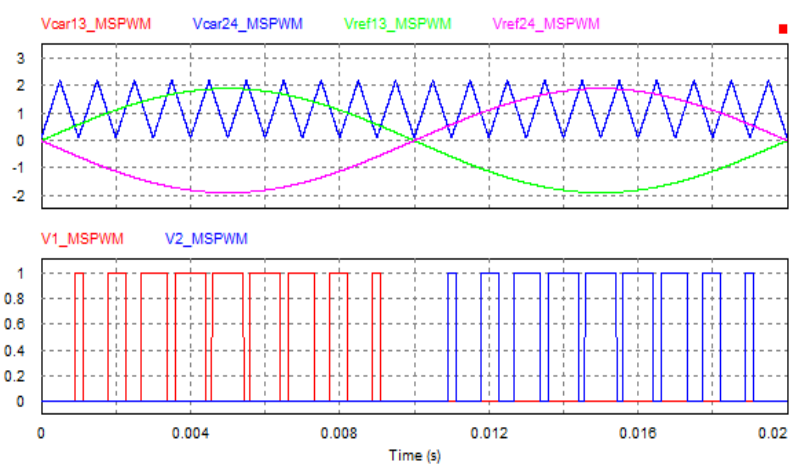

Gambar 6. Metode pemicuan modified unipolar SPWM

Pembangkitan sinyal kontrol inverter SPWM dilakukan dengan cara membandingkan gelombang sinus dan segitiga. Untuk membangkitkan gelombang sinus dan segitiga dibutuhkan IC pembangkit pulsa ICL8038. IC. Aplikasi pembangkitan SPWM tidak dapat menggunakan 1 buah IC karena frekuensi operasi gelombang sinus dan segitiga berbeda. Untuk itu, pembangkitan SPWM menggunakan 2 buah IC ICL8038 untuk membangkitkan gelombang sinus dan segitiga dengan frekuensi berbeda.

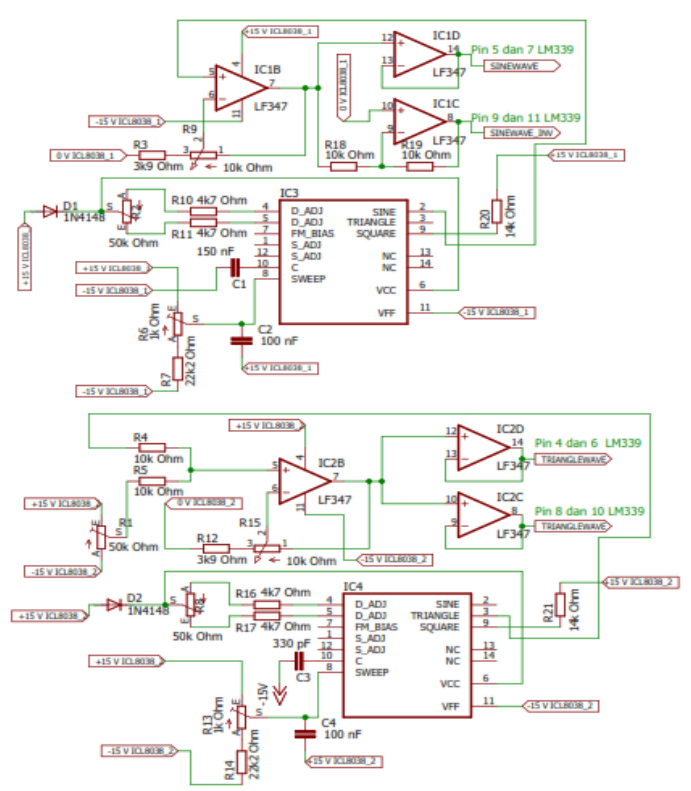

Gambar 7. Rangkaian pembangkit gelombang sinus dan segitiga

Rangkaian pada Gambar 7 hanya menghasilkan gelombang sinus dan segitiga, sehingga dibutuhkan komparator untuk membandingkan kedua gelombang tersebut yaitu dengan menggunakan IC komparator LM339 yang realisasi rangkaiannya menjadi 1 rangkaian dengan driver. Rangkaian LM339 dan driver akan ditampilkan pada subbab selanjutnya.

\subsection{Perancangan Rangakaian MOSFET/IGBT Driver}

Rangkaian driver dengan IC TLP250 digunakan pada kedua rangkaian kontrol DC chopper buck-boost dan inverter 1 fase Rangkaian driver pada DC chopper buckboost digunakan untuk mengisolasi dan menguatkan sinyal [14] PWM 5 V yang dibangkitkan mikrokontroler menjadi level tegangan yang lebih tinggi dengan sistem ground terpisah dan cukup untuk memicu MOSFET FMH23N50E dengan batas tegangan $V_{G S}$ maksimum $20 \mathrm{~V}$.

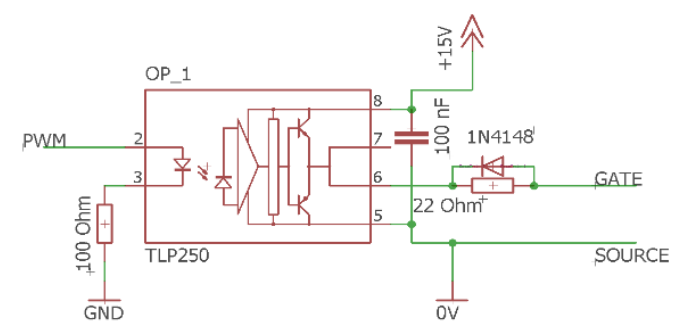

Gambar 8. Rangkaian MOSFET driver TLP250 
Rangkaian driver pada inverter memiliki fungsi yang hampir sama dengan MOSFET driver pada DC chopper. Inverter membutuhkan ground terpisah pada collector IGBT di sisi high inverter karena collector IGBT tersebut berhubungan langsung dengan emitter dari sisi low inverter. TLP250 dapat menguatkan arus hingga 1,5 A. Kemampuan IC kontrol hanya dapat menyuplai arus maksimal $25 \mathrm{~mA}$ sehingga membutuhkan penguatan arus. Selain itu, TLP250 dapat memperkecil delay on dan off pada IGBT akibat peristiwa pengosongan dan pengisian muatan pada IGBT.

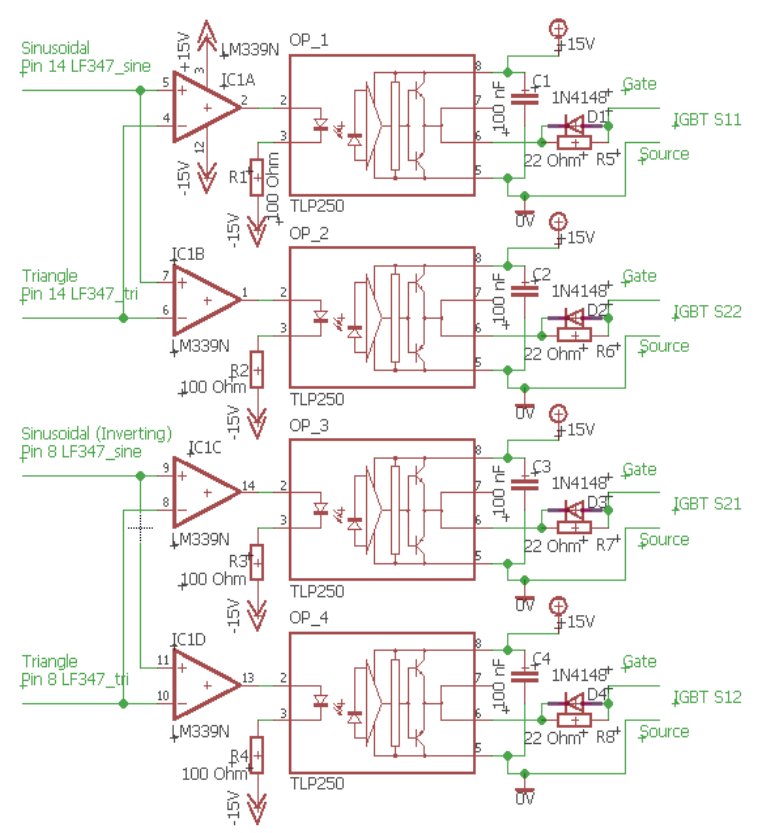

Gambar 9. Rangkaian IGBT driver TLP250 dan komparator LM339

\section{Hasil dan Analisis}

3.1. Pengujian Gelombang Kontrol MOSFET/IGBT

Gelombang pemicuan untuk DC chopper buck-boost dan inverter 1 fase akan diuji pada subbab ini. Pengujian gelombang pemicuan dilakukan untuk mengetahui apakah gelombang layak untuk memicu MOSFET/IGBT sehingga konverter bekerja dengan baik.

\subsubsection{Pengujian Gelombang PWM}

Gambar 10 menunjukkan gelombang pemicuan DC chopper buck-boost pada duty cycle $20 \%$. Pemicuan telah memiliki bentuk PWM yang kotak, yang berarti memiliki rise time dan fall time yang singkat sehingga proses on/off MOSFET dapat bekerja dengan baik. Gelombang PWM memiliki puncak tegangan sebesar $15 \mathrm{~V}$ yang dibutuhkan untuk mengaktifkan MOSFET. FMH23N50E membutuhkan tegangan threshold $\left(\mathrm{V}_{\mathrm{th}}\right)$ sebesar $2,5 \mathrm{~V}$ untuk aktif [15].

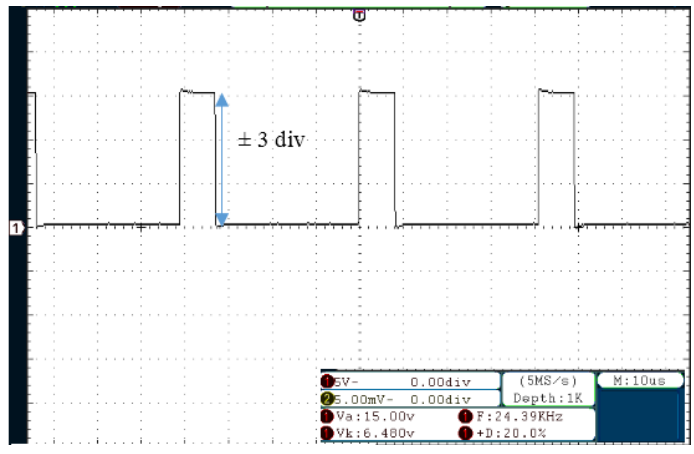

Gambar 10. Gelombang PWM pemicuan DC chopper buck-boost

\subsubsection{Pengujian Gelombang SPWM}

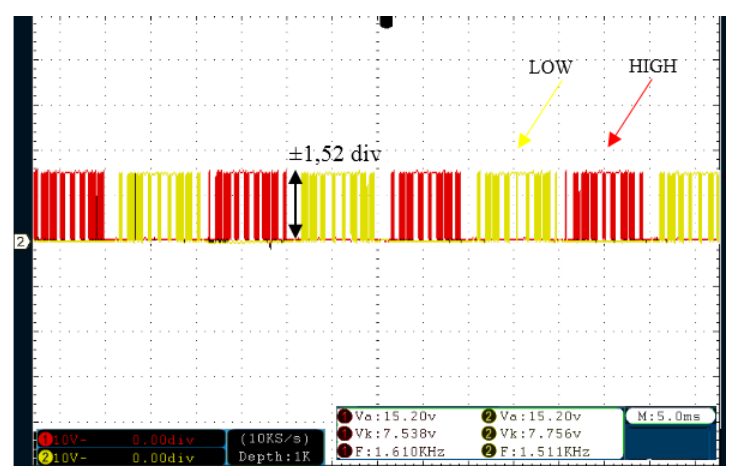

Gambar 11. Gelombang SPWM pemicuan inverter 1 fase

Gambar 11 menunjukkan gelombang pemicuan inverter 1 fase pada indeks modulasi $M_{a}=1$. Pemicuan telah memiliki gelombang SPWM yang saling bergantian antara pemicuan sisi HIGH dan LOW. Gap diantara sisi $\mathrm{HIGH}$ dan LOW merupakan dead-time yang berfungsi mencegah IGBT antara kedua sisi aktif secara bersamaan yang dapat menyebabkan terjadinya short circuit. Gelombang SPWM memiliki puncak tegangan sebesar 15,2 V yang dibutuhkan untuk mengaktifkan IGBT. G40N120 membutuhkan tegangan threshold $\left(\mathrm{V}_{\text {th }}\right)$ sebesar 3,5 V untuk aktif [11].

\subsection{Pengujian Keluaran Gelombang DC Chopper Buck-boost dan Konverter AC.}

Pengujian gelombang keluaran dilakukan untuk mengetahui kualitas gelombang keluaran serta kesesuaian tegangan keluaran dengan rumus yang berlaku.

\subsubsection{Pengujian Gelombang DC Chopper Buck-boost}

Gambar 12 menunjukkan hasil pengujian keluaran DC chopper buck-boost. Gelombang tegangan berbentuk garis lurus, namun terlihat beberapa riak tegangan. Riak tegangan paling tinggi bernilai $\pm 3,2$ div atau $320 \mathrm{~V}$ yang masih dalam batas kemampuan MOSFET FMH23N50E yaitu $500 \mathrm{~V}$ [28]. Nilai tegangan yang terukur pada 
osiloskop adalah $\pm 2,4$ div atau $240 \mathrm{~V}$. Nilai keluaran tegangan DC chopper buck-boost didapatkan dengan Persamaan (1).

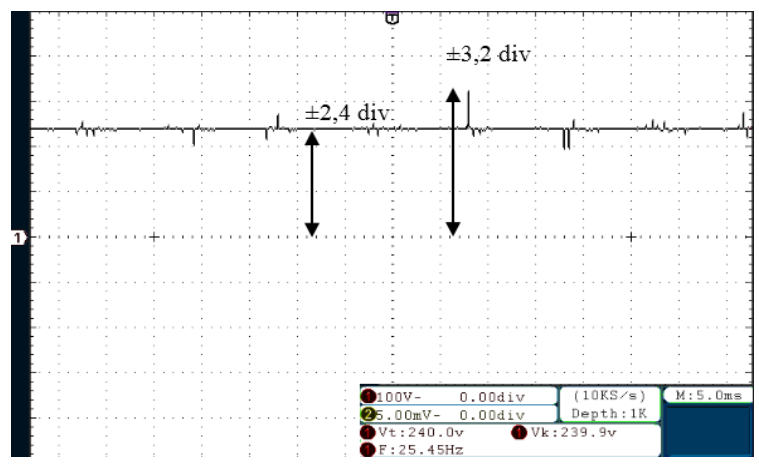

Gambar 12. Gelombang tegangan DC chopper buck-boost

$$
V_{o}=\frac{V_{S} \cdot D}{(1-D)}
$$

Diketahui sumber tegangan DC senilai 334,68 dan duty cycle $40 \%$, maka tegangan keluarannya adalah.

$$
\begin{aligned}
& =\frac{334,68 \cdot 0.4}{(1-0.4)} \\
& =223,16 \mathrm{~V}
\end{aligned}
$$

Berdasarkan perhitungan persamaan (1), tegangan keluaran DC chopper buck-boost senilai 223,16 V, sedangkan nilai terukur pada osiloskop $240 \mathrm{~V}$. Nilai terukur lebih besar dari nilai perhitungan, hal ini disebabkan oleh komponen parasitik yang tidak dipertimbangkan pada perancangan DC chopper buckboost. Perbedaan tegangan tidak terlalu signifikan sehingga perancangan dapat dikatakan sesuai dengan teori yang berlaku.

\subsubsection{Pengujian Gelombang Konverter AC}

Gambar 13 menunjukkan hasil pengujian keluaran inverter 1 fase dengan filter. Nilai tegangan keluaran inverter 1 fase didapat berdasarkan Persamaan 2 berikut ini.

$$
\begin{aligned}
V_{A C} r m s & =\frac{M_{a} \cdot V_{d c}}{\sqrt{2}} \\
& =\frac{1 \cdot 240}{\sqrt{2}} \\
& =168,70 \mathrm{~V}
\end{aligned}
$$

Tegangan keluaran inverter 1 fase berdasarkan Persamaan 2 senilai $168,70 \mathrm{~V}$, namun berdasarkan pengukuran osiloskop tegangan $\mathrm{RMS}\left(\mathrm{V}_{\mathrm{k}}\right)$ inverter 1 fase adalah 238,6 V. Tegangan keluaran inverter 1 fase dengan tegangan masukan DC-nya $(240 \mathrm{~V})$ memiliki tegangan yang hampir mendekati. Hal ini disebabkan oleh filter L-C perancangan memiliki damping ratio tidak akurat 0.7, sehingga frekuensi sekitar fundamendal mengalami gain yang seharusnya teredam [12]. Hasil pengujian ini digunakan sebagai referensi penentuan set point baru sehingga tidak terjadi over voltage pada sistem keluaran AC AVR.

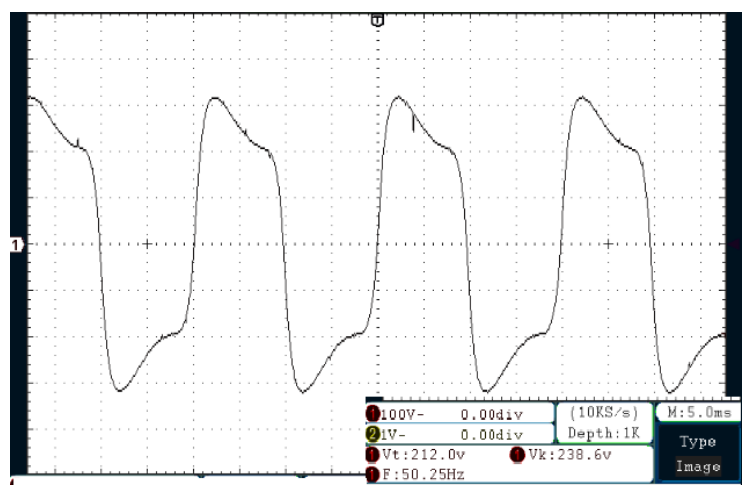

\begin{tabular}{|c|c|c|c|c|c|c|}
\hline \multirow[b]{2}{*}{$\begin{array}{l}V_{\text {in }} \\
\text { (V) }\end{array}$} & \multicolumn{2}{|c|}{$\begin{array}{c}\text { Beban }=204,29 \\
\Omega\end{array}$} & \multicolumn{2}{|c|}{$\begin{array}{c}\text { Beban }=128,15 \\
\Omega\end{array}$} & \multicolumn{2}{|c|}{ Beban $=76,17 \Omega$} \\
\hline & $\begin{array}{l}V_{D C} \\
(V)\end{array}$ & $\begin{array}{l}V_{\text {out }} \\
\text { (V) }\end{array}$ & $V_{D C}(\mathrm{~V})$ & $\mathrm{V}_{\text {out }}(\mathrm{V})$ & $V_{D C}(\mathrm{~V})$ & $V_{\text {out }}(\mathrm{V})$ \\
\hline 171,50 & 229,62 & 239,08 & 228,00 & 228,12 & 230,11 & 214,61 \\
\hline 180,99 & 228,82 & 239,61 & 229,16 & 228,21 & 229,88 & 215,34 \\
\hline 190,81 & 229,81 & 240,02 & 229,88 & 228,63 & 229,54 & 214,88 \\
\hline 200,35 & 230,78 & 239,13 & 229,18 & 228,36 & 229,68 & 215,00 \\
\hline
\end{tabular}

Gambar 13. Gelombang tegangan konverter AC

3.3. Pengujian Automatic Voltage Regulator (AVR) tehadap Tegangan Jatuh

Tabel 2. Data pengujian tegangan DC chopper dan keluaran AC AVR

Hubungan tegangan sumber dan beban terhadap tegangan konverter disajikan dalam grafik pada Gambar 11.

Gambar 14(a) terdiri dari 2 grafik analisis. Gambar 14(a) menunjukkan hubungan antara tegangan sumber dan beban terhadap tegangan DC chopper. Tegangan keluaran DC chopper cenderung stabil pada keadaan tegangan jatuh. Perubahan beban pada grafik direpresentasikan dengan perbedaan warna garis pada grafik. Ketiga grafik terlihat saling berhimpit yang berarti perubahan beban tidak berpengaruh terhadap keluaran tegangan DC chopper, sehingga hasil pengujian membuktikan tegangan DC chopper dapat stabil pada implementasi sistem AVR.

Gambar 14(b) menunjukkan hubungan antara tegangan sumber dan beban terhadap tegangan inverter. Tegangan keluaran DC chopper cenderung stabil pada keadaan tegangan jatuh. Ketiga grafik beban terlihat memiliki gap satu sama lain yang berarti perubahan beban mempengaruhi tegangan keluaran inverter, semakin besar 
nilai beban yang diberikan maka penurunan nilai tegangan inverter akan semakin besar. Nilai tegangan paling besar dan kecil berturut - turut adalah 239,08 V dan 214,61 V. Menurut SPLN 1:1995 [16] standar tegangan rendah PLN adalah $230 \mathrm{~V}$ dengan deviasi $5 \%$ dan $-10 \%$, sehingga tegangan keluaran inverter memenuhi standar PLN. Penurunan tegangan inverter disebabkan oleh rugi - rugi daya inverter dan filter.

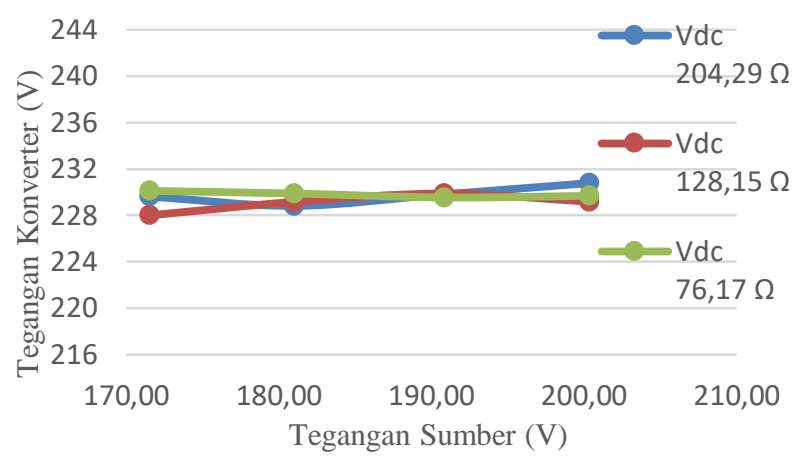

(a) DC chopper

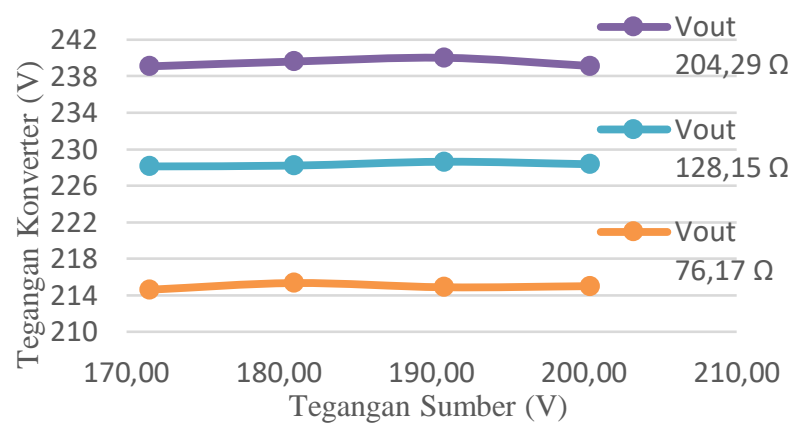

(b) Keluaran AVR

Gambar 14. Grafik hubungan $V_{\text {in }}-V_{\text {DC }}$ dan $V_{\text {in }}-V_{\text {out }}$

\section{Kesimpulan}

Konverter dirancang sebagai implementasi dari sistem Automatic voltage regulator (AVR). Konverter dapat bekerja open-loop dan close-loop. Variasi duty cycle membuktikan bahwa perubahan tegangan keluaran $\mathrm{AC}$ proposional dengan keluaran tegangan $\mathrm{AC}$ konverter. Variasi duty cycle nilai $10-40 \%$ menghasilkan hasil keluaran tegangan rata - rata AC berturut - turut sebesar 40,22 V, 88,57 V, 49,04 V, dan 226,31V. Konverter dengan sistem kerja close-loop atau dengan kerja AVR terbukti telah mengalami peningkatan level kestabilan tegangan yang dihasilkan, sehingga dapat AVR berhasil direalisasikan dan dapat menghasilkan tegangan yang memenuhi standar SPLN 1:1995. Konverter dengan implementasi AVR dapat menghasilkan tegangan keluaran DC rata - rata sebesar 229,54, tegangan AC 228,56 V, dan frekuensi 50,25 Hz. Sistem AVR lebih lanjut dapat menggunakan sensor pada tegangan inverter sebagai referensinya sehingga rugi - rugi filter $L-C$ akibat beban dapat diatasi, selain itu penggunaan filter aktif merupakan solusi untuk memperkecil harmonisa yang tidak dapat ditapis oleh filter pasif $L-C$. Penelitian selanjutnya dapat mempertimbangkan topologi DC chopper lainnya, seperti buck, boost, cuk dan SEPIC.

\section{Referensi}

[1]. Kementrian ESDM, Statistik Ketenagalistrikan 2015. Jakarta, 2014.

[2]. Michael Agustinus - detikFinance, "Tegangan Listrik Pelanggan Naik Turun, Ini Penjelasan PLN," 2017. [Online]. Available: https://finance.detik.com/energi/3573554/teganganlistrik-pelanggan-naik-turun-ini-penjelasan-pln. [Accessed: 03-Sep-2017].

[3]. Balikpapan News | Portal Kalimantan, "Tegangan Listrik Naik Turun," 2016. [Online]. Available: http://balikpapan.prokal.co/read/news/183381-teganganlistrik-naik-turun.html. [Accessed: 03-Sep-2017].

[4]. Rakyat Sulsel, "Tegangan Listrik Naik Turun, Dewan Maros Meradang," 2014. [Online]. Available: http://rakyatsulsel.com/tegangan-listrik-naik-turundewan-maros-meradang.html. [Accessed: 03-Sep-2017].

[5]. Daniel W.Hart, Power Electronics. McGraw-Hill, 2011.

[6]. Megastar Electroniques Inc, "Single-Phase Bridge Rectifier KBPC35005-KBPC3510," Datasheet KBPC3510.

[7]. M. K. Kazimierczuk, Pulse-width modulated DC-DC power converters. Wiley, 2008.

[8]. M. H. Rashid, Ed., Power Electronics Handbook: Devices, circuits, and applications, 3rd ed. Oxford: Butterworth-Heinemann, 2011.

[9]. B. P. Chacko, V. N. Panchalai, and N. Sivakumar, "Modified Unipolar Switching Technique for PWM Controlled Digital Sonar Power Amplifier," Int. J. Eng. Innov. Technol. Vol., vol. 3, no. 5, pp. 147-154, 2013.

[10]. J. C. Pati and J. K. Sahu, "Harmonic Analysis by Using Various PWM Techniques and Their Comparison," Int. J. Adv. Res. Sci. Technol. Int. J. Adv. Res. Sci. Technol., vol. 1, no. 1, pp. 35-44, 2012.

[11]. Fairchild, "FGL40N120AND 1200V NPT IGBT," Datasheet FGL4ON120AND, 2008.

[12]. Texas Instrument, "LC Filter Design," 2016.

[13]. D. A. K. S. Anjana Thakur, "An Overview of Different PWM Techniques to Reduce Total Harmonic Distortion of Output in H-Bridge Inverter," Int. J. Recent Res. Electr. Electron. Eng., vol. 3, no. 2, pp. 65-69, 2016.

[14]. TOSHIBA, "Photocoupler GaAlAs Ired \& Photo-IC TLP250," vol. 5, pp. 1-8, 2004.

[15]. Fuji Electric Device Technology, "FMH23N50E FUJI POWER MOSFET Super FAP-E 3 series," Datasheet FMH23N5OE, 1996.

[16]. SPLN 1:1995 Tegangan Standar. Jakarta: PT. Perusahaan Listrik Negara (Persero), 1995. 